\title{
A Case of Primary Laryngeal Aspergillosis Confused with Vocal Cyst
}

\author{
Young In Kim, Byoung Chul Park, Jang Su Lee and Han Ki Min \\ Department of Otorhinolaryngology, Kwangju Christian Hospital, Gwangju, Korea
}

\author{
성대낭종으로 오인된 원발성 후두 국균증 1 예 \\ 김영인 · 박병철 · 이장수 · 민한기 \\ 광주기독병원 이비인후과
}

Received September 27, 2010

Revised October 7, 2010

Accepted October 12, 2010

Address for correspondence

Young In Kim, MD

Department of Otorhinolaryngology,

Kwangju Christian Hospital,

37 Yangnim-ro, Nam-gu,

Gwangju 503-715, Korea

Tel $+82-62-650-5095$

Fax $+82-62-650-5090$

E-mailnnicekyi@naver.com
With a surge in the population of immunocompromised patients, the incidence of laryngeal fungal infection has also been increased. Infection by aspergillus, which is a kind of mold, or a filamentous fungus, occurs rarely in larynx. Furthermore, most aspergillosis of the upper airway is an extension of the pulmonary or systemic aspergillosis in the immunocompromised host. So, the primary laryngeal aspergillosis that occurrs as an isolated laryngeal infection of aspergillus without other aerodigestive tract extension is very rarely encountered. We present a case of primary laryngeal aspergillosis misconceived as a vocal cord cyst in a 24-year-old female who had no past history of immune deficiency, voice abuse or steroid use. Korean J Otorhinolaryngol-Head Neck Surg 2010;53:726-8

\section{서 론}

국균(aspergillus)은 흙과 썩은 과일 등에서 발견되는 포 자가 많은 대표적인 진균의 일종으로, 흡인에 의해 감염되 고 주로 폐나 기관지 등에서 발생한다. 최근 면역기능 저하 환자의 증가에 따라 진균 감염의 발생의 빈도가 증가하고 있지만 후두의 진균감염은 비교적 드문 질환이다. 후두 국 균증은 면역저하 환자에서 전신적 침입 후 기관이나 기관지 로부터 발생한 속발성이 대부분이며, 후두에 국한되어 발생 하는 원발성 국균증(aspergillosis)은 매우 드물다. 원발성 후두 국균증은 전세계적으로 19예가 보고 되었고, 국내에 서도 2002년에 1예만 보고 되었다. ${ }^{1-4)}$ 또한 성대낭종 형태 의 원발성 국균증은 더욱 드물어 전세계적으로 1 예가 보고 되었고 ${ }^{5}$ 국내에서는 아직 보고된 예가 없다. 저자들은 성대 낭종으로 오인된 원발성 후두 국균증 1 예를 치험하였기에 문헌 고찰과 함께 보고하는 바이다.

\section{증 례}

24 세 여자환자로 3 개월 전부터 시작된 음성변화를 주소 로 내원하였다. 술과 담배 그리고 음성남용은 없었으며 후 두외상을 입은 과거력은 없었다. 또한 동반된 전신질환이나 면역기능 저하를 의심할만한 소견은 없었다. 생체활력징후 는 정상이었고, 이학적 검사 시 시행한 굴곡형 후두경 소견 상 우측 진성대의 전방 $1 / 3$ 지점에 직경 약 $2 \sim 3 \mathrm{~mm}$ 크기의 무경성 종물이 보였고(Fig. 1), 주위의 후두개, 양측 이상 와, 피열연골 등에는 이상소견은 보이지 않았다. 후두 스트 로보스코피상 낭종형태가 비교적 잘 보이고 점막파동이 종 물부분에서 단절되는 성대낭종과 부합되는 소견이 보였다. 혈액검사상 호중구 감소나 빈혈소견 없는 정상소견 보였고, 기타 간기능 검사와 요검사상 정상이었다. 객담검사나 흥부 단순 촬영상 결핵 혹은 폐기관지 국균증의 증거는 없었다. 전신마취하에 후두미세수술을 시행하였고 병변 외측에 성 대와 평행하게 절개를 넣어 미세피판을 만든 다음 주변 진 
성대는 보존하면서 낭종을 천천히 노출시켰다(Fig. 2). 피판 을 들어올리면서 경계가 불명확한 백색의, 잘 부서지고 무 른 형태의 물질이 나왔는데 조직병리검사상 45 도의 가지를 내면서 격막을 가진 균사가 보이는 국균증의 특징적인 소견 을 보였다(Fig. 3). 술 후 1주일, 1 개월째 그리고 3 개월째 외 래경과 관찰하였고 음성의 변화나 이학적 검사상 병변의 재 발소견 보이지 않았다.

\section{고 찰}

국균증은 흡입에 의해 숙주의 상기도로 침입을 하며, 병 인과 주로 관련되는 종으로는 A. fumigatus 가 가장 많으며 다음으로 A. niger, A. flavus 가 있다. 흔한 침범 부위로는 기 관(trachea), 기관지(bronchi), 폐, 부비동, 귀, 눈이고, 혈류 를 타고 자주 파급되는 기관(organ)은 폐, 심장, 뇌, 콩팥, 간, 비장, 골격, 뇌막 및 혈액 등이다. 국균은 사상균(mold) 의 일종으로 Cadida와 같은 효모균(yeast)에 비교하여 기 관 기관지 감염만을 일으키고 후두로 파급의 빈도는 낮다고 한다. $^{2-4)}$ 국균증은 한국인의 진균증 중 약 $18.5 \%$ 를 차지하 며 남녀의 비는 $2: 1$ 이고 모든 연령층에서 발생할 수 있다. ${ }^{6)}$

국균증을 포함한 진균의 후두 감염은 비교적 드물지만 대

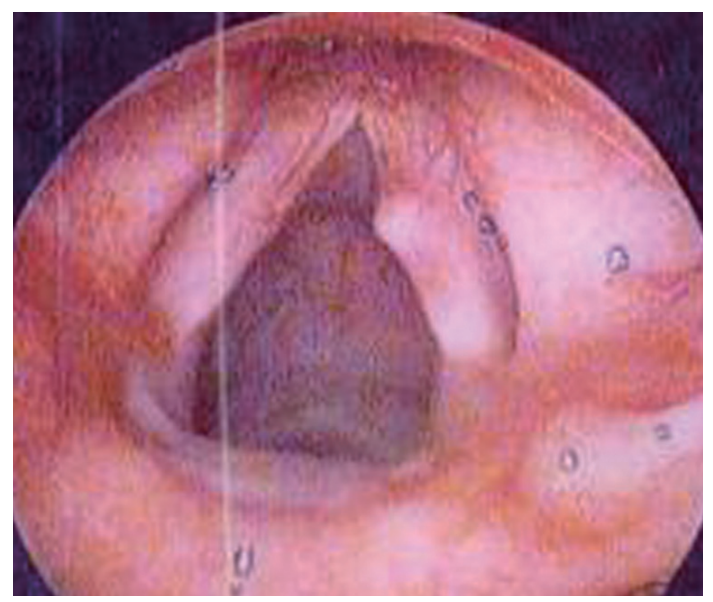

Fig. 1. Direct laryngoscopy finding shows $2-3 \mathrm{~mm}$ sized sessile mass of the midportion of the right vocal cord, consistent in appearance with a true vocal cord cyst.
개 전신적 발현의 일부로, 또는 면역저하환자에서 단독으로 발생하기보다는 폐기관지 질환의 속발성으로 일어날 수 있다. 역저하의 요인에는 외부적으로는 높은 습도 및 환자의 저항 성을 낮출 수 있는 세포독성제와 항암제, 장기간의 스테로이 드 사용 그리고 방사선 치료 등이 있으며, 내부적으로는 백혈 병, 림프종, 호중구감소 및 범혈구감소증, 결핵 등이 있다. ${ }^{4)}$

국균증은 모든 기관에서 발생할 수 있으나 일반적으로 호흡기에서는 숙주의 면역상태에 따라 두 가지 형태로 나타 난다. 하나는 면역기능이 정상인 숙주에서는 부비동, 눈, 귀, 후두, 외이도에서 국소적으로 발생하는 경우이고, 다른 하나는 면역기능이 저하된 환자군에서 침습적으로 발생하 는 경우이다.') 알레르기성 국균증은 주로 천식의 과거력이 있는 환자에서 기관지 천식 형태로 발병하며 비아토피성 사 람에서는 흡입한 알레르기성 포자가 과민반응을 일으켜 폐 포염을 유발한다. 부비동에서는 숙주의 면역상태에 따라 국 균종(aspergilloma), 급성 전격성 국균증(acute fuminant aspergillosis), 만성 무통성 국균증(chronic indolent aspergillosis), 알레르기성 부비동 국균증(allergic aspergillus sinusitis) 등의 형태로 나타난다. 또한 국균종은 숙 주의 면역이 정상인 경우 흔히 상악동 내에 국한된 종괴양 상으로 나타나고, 전격성 국균증은 면역억제 상태에서 기회 감염으로 생겨 상피층을 파괴하고 인접조직으로 침투하여

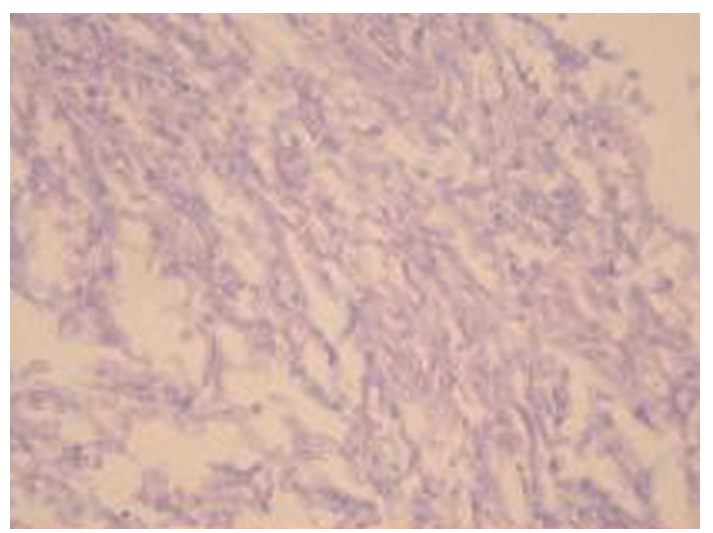

Fig. 3. Histopathologic finding of tissue from cystic mass on true vocal cord presents aspergillus fungi with characteristic hypae and 45 degree angled branching pattern (H\&E stain, $\times 200$ ).
Fig. 2. Intraoperative endoscopic finding shows the cystic mass on right side of true vocal cord $(A)$ and vocal cord after mass excision (B).
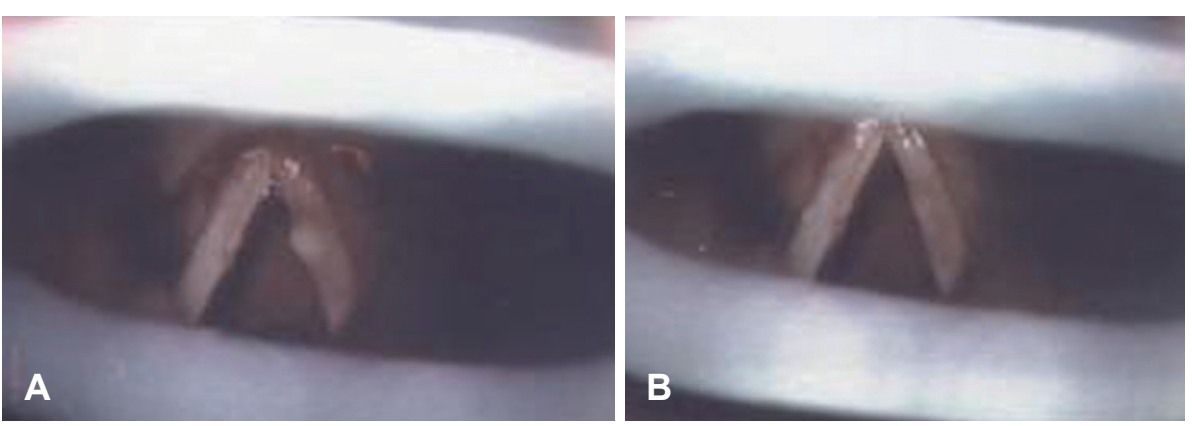
증상을 유발한다. 만성 침윤성 국균증은 면역기능이 정상 인 환자에서도 발생할 수 있는데 조직괴사의 결과로 육아종 성 염증반응을 일으킨다. 침윤성 국균증의 경우 대부분 이 차적으로 발생하고 백색의 궤양 형태로 나타나며 성대의 운 동성 감소와 연골의 노출 등을 보였다. 외이도에서 발생하 는 국균증을 이진균증(otomycosis)이라고 하고 대개는 탈 락된 각설이나 이구를 통해 자라므로 침습적이지 않고 기저 의 외이도염의 치료가 중요하다. 안구에서 각막손상이 동반 된 경우에 국소적인 감염을 일으켜 국균 각막염(aspergillus keratitis)이 병발할 수 있다. $5,6,8)$

Wittkopf 등은 이전에 보고된 후두 국균종 14예를 분 석하여, 5 예는 기관기관지감염으로부터 기인한 이차적인 감 염이며, 9예는 후두에만 국한된 경우로 그 중 7예는 면역 저하가 없는 환자에서 발생한 국균증으로 보고하였다. 이들 은 이전 원발암에 대한 방사선 치료, 레이저 그리고 흡입성 스테로이드 사용 등의 의인성 손상에 의해 발생한 증례들 로, 의인성 손상을 원발성 후두 감염의 중요한 요인의 하나 로 보고하였다. 또한 의인성 손상이 명확하지 않는 낭종 형 태의 원발성 후두 국균종을 보고하였는데, 낭성질환 발생 후 이차적인 감염에 의해 발생한 후두 국균증인지, 우연히 발생한 후두손상 후 흡입되어 감염되거나 상재되어 있던 국 균의 감염으로 일어난 것인지에 대해 증례가 드물고 연구도 부족하여, 명확히 설명하지는 못하였다.

후두 진균증은 조직소견이 암종과 혼동될 수 있어서 각 화증(acanthosis), 미세농양(microabscess), 가성상피 과 증식증(pseudoepitheliomatous hyperplasia), 만성 염증 이 있다면 진균증을 의심하고 즉시 검사를 해야하고, 또한 진단하게 되면 치료될 수 있는 질환이므로 후두 진균증의 정확한 진단은 중요하다 하겠다. ${ }^{1,3,6)}$

진단은 배양 시 진균의 반복적인 분류동정이 확인되어야 하며 국균증이 의심되는 경우 혈청학적 검사가 도움이 될 수 있다. 진균증의 최종 진단은 반드시 병리학적인 조직으로 내려야 하며 이는 진균배양에서 양성의 결과는 단지 공생 진균류를 나타낼 수도 있기 때문이다. 병리조직학적인 국균 의 특징으로는 많은 격벽과 분지된 균사가 약 $45^{\circ}$ 로 배열되 어 형성된 균사괴를 관찰해야 하며, 침윤형에서는 균사가 주위의 조직 실질로 침윤되어 조직을 괴사 화농시키는 양상 을 볼 수 있으며 혈전증과 수산증(oxalosis)으로 인한 수산 화칼슘(calcium oxalate) 결정 등을 관찰할 수 있다. ${ }^{2,9,10)}$

본 예는 전신질환이나 면역저하소견이 없는 젊은 여성에 서 발생하였고, 뚜렷하게 성대 중간부위에 생긴 무경성 성 대 낭종의 형태를 보이며, 점막하층이나 주변 구조물로는 침범 소견을 보이지 않는 원발성 후두 국균증이다. 성대낭
종은 보통 표피양낭과 점액저류낭으로 나뉘는데 선천적 잔 여물이나 음성과용 후 손상된 상피가 파묻히거나 염증이나 외상 후 점액분비선의 폐쇄가 원인이다. 환자는 이전 후두 에 의인성 손상이나 음성남용이 있을만한 직업적 소인은 없 었고, 수술 시 점막층을 들어올리면서 나오는 백색의 물질은 명확한 낭의 형태를 갖추고 있지 않는 점막하 국균종(submucosal aspergilloma) $)^{5}$ 과 흡사하였다. 결론적으로 본례 가 낭성질환 발생 후 이차적인 감염에 의한 것인지, 우연히 발생한 후두감염에 의한 것인지 명확히 구분하기는 힘들것 으로 보인다. 다만 조직검사 결과 낭을 형성하는 상피조직 이 없었고, 수술소견도 국균종 형태와 흡사한 것으로 보아 후 자처럼 손상된 상피에 상기도내에 상재되어 있던 국균의 우 연한 감염에 의한 것으로 사료된다.

후두 국균증의 치료는 감염의 형태나 침범의 정도에 따라 차이가 있다. 대개 침윤성의 국균증은 전신적인 항진균제의 투여, 원인질환 치료 및 필요시에는 침범부위에 대한 수술 적 절제가 필요하며, 비침윤성 질환은 전신적인 치료없이 국소적인 제거로 충분하지만 전신적 질환이나 면역저하가 동반된 환자의 경우에는 국소적인 제거 후 항진균제 국소도 포가 도움이 된다. ${ }^{1,3,9)}$

저자들은 성대낭종으로 오인된 원발성 후두 국균증 1 예 를 수술적 제거 후 재발없이 치료하였기에 문헌고찰과 함께 이를 보고하는 바이다.

\section{REFERENCES}

1) Kim DJ, Hwang EG, Kim JP. A case of primary laryngeal aspergillosis. Korean J Otolaryngol-Head Neck Surg 2002;45(4):422-4.

2) Ahn JH, Kim YJ. Invasive aspergillosis of maxillary sinus invading skull base: report of a case. Korean J Otolaryngol-Head Neck Surg 1999;42(5):652-5.

3) Richardson BE, Morrison VA, Gapany M. Invasive aspergillosis of the larynx: case report and review of the literature. Otolaryngol Head Neck Surg 1996;114(3):471-3.

4) Ferlito A. Primary aspergillosis of the larynx. J Laryngol Otol 1974;88(12):1257-63.

5) Wittkopf J, Connelly S, Hoffman H, Smith R, Robinson R. Infection of true vocal fold cyst with Aspergillosis. Otolaryngol-Head Neck Surg 2006;135(4):660-1.

6) Korean society of Otorhinolarngology-Head and Neck Surgery. Otorhinolarngology-Head and Neck Surgery. $2^{\text {nd }}$ ed. Seoul: Il-chokak;2009. p.426.

7) Benson-Mitchell R, Tolley N, Croft CB, Gallimore A. Aspergillosis of the larynx. J Laryngol Otol 1994;108(10):883-5.

8) Min YG, Kang MK, Lee JW, Choo MJ, Lee KS. A clinical study on mycotic sinusitis. Korean J Otolaryngol-Head Neck Surg 1993;36(2): 292-301.

9) Kingdom TT, Lee KC. Invasive aspergillosis of the larynx in AIDS. Otolaryngol Head Neck Surg 1996;115(1):135-7.

10) Ma YW, Hong SK, Jeon SY, Hwang EG, Kim CS, Kim JP. A clinical study on aspergillus sinusitis. Korean J Otolaryngol-Head Neck Surg 1993;36(4):727-33. 